\title{
EXPERIMENTAL STUDY OF THE COMBUSTION DYNAMICS OF RENEWABLE \& FOSSIL FUEL CO-FIRE IN SWIRLING FLAME
}

\author{
M. Zaķe ${ }^{1}$, I. Barmina ${ }^{1}$, V. Krishko², M. Gedrovics ${ }^{2}$, A. Desņickis ${ }^{2}$ \\ ${ }^{1}$ Institute of Physics, University of Latvia, \\ 32 Miera Str., Salaspils LV-2169, LATVIA \\ ${ }^{2}$ Faculty of Power and Electrical Engineering, Riga Technical University, \\ 1 Kronvalda Blvd., Riga LV-1010, LATVIA
}

\begin{abstract}
The complex experimental research into the combustion dynamics of renewable (wood biomass) and fossil (propane) fuel co-fire in a swirling flame flow has been carried out with the aim to achieve clean and effective heat production with reduced carbon emissions. The effect of propane co-fire on the formation of the swirling flame velocity, temperature and composition fields as well as on the combustion efficiency and heat output has been analysed. The results of experimental study show that the propane supply into the wood biomass gasifier provides faster wood fuel gasification with active release of volatiles at the primary stage of swirling flame flow formation, while the swirl-induced recirculation with enhanced mixing of the flame components results in a more complete burnout of wood volatiles downstream of the combustor with reduced mass fraction of polluting impurities in the emissions.
\end{abstract}

Key words: combustion dynamics, swirling flow, co-firing, renewables, fossil fuel, greenhouse gases.

\section{INTRODUCTION}

As a result of human activities, greenhouse gases, such as carbon dioxide $\left(\mathrm{CO}_{2}\right)$ and methane $\left(\mathrm{CH}_{4}\right)$, are still increasing in the Earth's atmosphere causing its temperature to rise, which would lead to even greater global warming during this century. To minimize the potential impact of human activities on the global climate changes, various types of greenhouse gas mitigation technologies are being evaluated with account of costs and impacts on the ecology systems [1-3]. Replacing of fossil fuels with renewable energy sources is one of the most promising tasks. Wood biomass is still an abundant self-renewing material throughout the world. As a renewable energy resource, biomass has some indisputable advantages when compared with other renewable sources; for example, wood biomass is widely available, its conversion facilities require comparatively low capital costs and can be integrated into existing fossil-fuelled power generation plants. The main attractiveness of wood biomass as fuel is associated with carbon dioxide, because the growth of trees and their conversion to energy as biomass fuels recycles atmospheric carbon, thus not adding $\mathrm{CO}_{2}$ to the atmosphere. Besides, the low sulphur contents of most biomass materials means that the emissions of $\mathrm{SO}_{2}$ (acid gas resulting in the acid rains) are minimized [2]. However, conventional woodfuelled heating systems are not efficient because of dissimilar structure and 
different moisture content of wood fuels. As a result, up to half the gasified fuel products and the heat of conventional wood fires can be lost up the chimneys. A low-cost option for more effective and cleaner conversion of biomass - one of the largest world's energy sources - to the heat energy is the co-firing, i.e. the simultaneous combustion of different types of fuels in the same boiler, with fossil fuel partially replaced by renewable. Co-firing is an environmentally-friendly and cheap method of mixing wood biomass with coal $[4,5]$ or the flow of volatiles with gaseous fuel (natural gas, propane [6,7]). Among the major factors affecting combustion - its efficiency, formation of polluting emissions by co-firing the wood fuel with gas, etc., is the flow dynamics that determines the formation of flame structure. To improve combustion conditions with benefit to the ignition, flame stability and emission reduction, the very promising technique is swirling combustion [8-10]. Swirling flows with lean fuel $\&$ air premixing and the formation of a central recirculation zone provide stable combustion with effective emission reduction. The previous experimental study of co-firing wood biomass with propane [11] has shown that the swirling flame structures and combustion characteristics can be closely linked to the features of the swirling airflow field determining the swirling flame flow formation with recirculation, which improves mixing and combustion of the flame components [11]. Therefore the very important factor that determines the intensity of wood fuel gasification and the development of combustion characteristics downstream of the combustor is the rate of gas co-firing [12]. The previous investigations have also shown that the direct propane co-fire of wood biomass with an additional heat supply into a wood layer results in faster thermal decomposition of wood pellets, which facilitates ignition and burnout of the volatiles. In fact, the measurements of the flame characteristics at different rates of propane co-fire have shown that during the primary stage of swirling flame formation the increase in the rate of propane co-fire can result in an ignition delay with relatively high release of polluting $\mathrm{CO}$ and NO emissions. Such being the case, the swirling combustion with recirculation can be used to improve the combustion characteristics downstream of the swirling flame flow, completing burnout of volatiles with greater heat output, higher temperatures inside the flame reaction zone, and better release of $\mathrm{CO}_{2}$ emissions. For this reason, the motivation of this research was to investigate the impact of the propane co-fire on the flame velocity, temperature and composition fields and to reveal the main factors affecting the balance between the enhanced wood fuel gasification by co-firing with propane flame flow and the swirl-enhanced burnout of volatiles. As shown, more effective burnout of volatiles and cleaner combustion of wood fuel can be achieved by minimizing the impact of propane co-fire on the formation of polluting emissions.

\section{EXPERIMENTAL}

The pilot device for experimental study of combustion dynamics downstream of the swirling flame flow at co-firing discrete doses of renewable wood fuel (up to 300-500 g) with fossil fuel (propane) is shown in Fig. 1 [12]. The main elements of the device are: wood fuel gasifier (1), propane burner (2), and combustor (3). The primary (4) and secondary (5) swirling air supplies below and above the layer of wood biomass (wood pellets) are provided using two tangential inlets $3 \mathrm{~mm}$ in diameter determining the swirling flame flow formation and mixing 


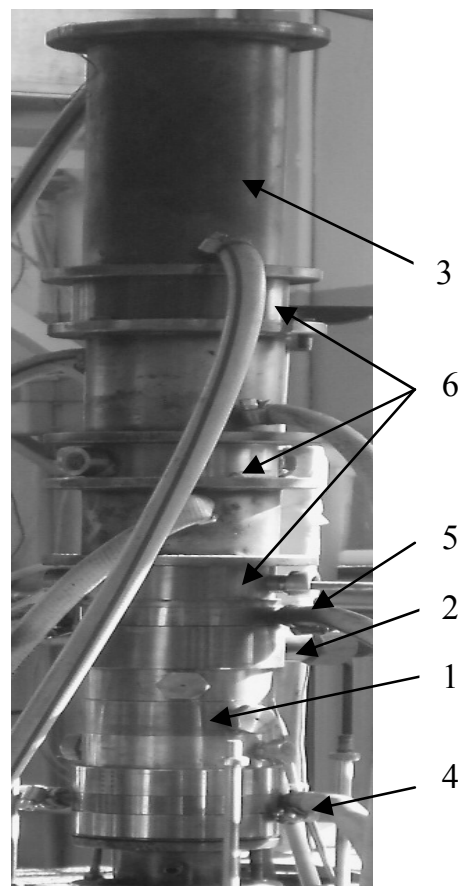

Fig. 1. Setup for experimental study of the swirling flame flow dynamics the propane flame flow. by co-firing of wood biomass with

of the flame components. The primary air supply supports the wood fuel gasification, while the secondary airs supply - combustion of the volatiles downstream of the combustor. The experimental study of the effect exerted by the rate of propane co-fire on the combustion dynamics was carried out at constant primary and secondary air supply rates of $401 / \mathrm{min}$ and $701 /$ min, with the mean air excess of up to 2.5 3 , by varying the rate of propane supply in the range from 0 up to $0.83 \mathrm{l} / \mathrm{min}$ (corresponding to the variations in the additional heat supply into the upper part of the layer of wood pellets in the range of $0-1.25 \mathrm{~kJ} / \mathrm{s}$ and the ratio of additional heat supply from propane combustion up to 30 $35 \%$ ). The local measurements of the flame velocity, temperature, composition and combustion efficiency at different stages of the swirling flow field formation were carried out to estimate the effect of the propane co-fire rate on the combustion dynamics.

The experimental study of the combustion dynamics impact on the flame formation and the local flame composition includes experimental research into the formation of the

flame velocity and temperature fields, heat production rate and composition of the products at different stages of the wood fuel burnout. The diagnostic sections (6) with peepholes are placed between the sections of water-cooled combustor (3) and were used for the local input of different diagnostic tools (thermocouples, gas sampling probes, Pitot's tube) into the swirling flame flow to provide the local measurements of the flame parameters (its velocity, temperature and composition) at different stages of the swirling combustion. The local measurements of the flame temperature were taken using $\mathrm{Pt} / \mathrm{Pt}-\mathrm{Rh}(10 \%)$ thermocouples and PC-20TR software. In particular, the use of this software allowed for the estimation of the average heat production rate at different stages of the swirling flame formation from the calorimetric measurements of cooling water flow. The local variations in the swirling flame velocity, temperature, composition of the products $\left(\mathrm{NO}_{\mathrm{x}}, \mathrm{CO}_{2}\right.$, $\mathrm{CO}, \mathrm{O}_{2}$ ) and combustion efficiency at different stages of the flame formation and different rates of propane co-fire were on-line registered using the software of a gas analyzer Testo 350XL with a $1 \mathrm{~s}$ time interval between measurements. Each of the parameters: the average velocity and the composition, were estimated from 10 15 measurements.

\section{RESULTS AND DISCUSSION}

\subsection{The main factors of the formation of swirling flow velocity field.}

The previous experiments have shown $[11,12]$ that the formation of swirling flame flow velocity and composition profiles at the air excess supply into the 
combustor and the constant rate of wood fuel co-fire with propane are closely connected with the swirl configuration and the primary \& secondary air supply rates determining the swirl intensity.

The experimental modelling of the effect of primary and secondary air supply on the formation of the velocity field of cold confined swirling airflow above the layer of wood pellets has shown that, as concerns the swirling airflow velocity profiles formed, they are mainly sensitive to variations in the secondary swirling air supply, and at constant primary \& secondary air supply rates they rapidly decay downstream of the combustor, indicating the formation of a pronounced recirculation zone where the axial flow rate is balanced by recirculation of the swirling airflow (Fig. $2 a-f$ ). The estimation of the cold airflow conditions nearby a secondary air nozzle varying the rate of the primary air supply in the range of $40-551 / \mathrm{min}$ and the secondary air supply rate in that of 60 $100 \mathrm{l} / \mathrm{min}$ shows the formation of a highly turbulent flow field above the wood pellets with the air swirl number variations $S=0.6-1.4$ (where $S \approx 2 / 3^{*} \operatorname{vtg} / \mathrm{vax}$ ) and the Reynolds number being $\mathrm{Re}=3600-9000$. A typical formation of the cold airflow velocity profiles close to the outlet of secondary air nozzle $(L / D=0.5)$ at different primary \& secondary air supply rates is illustrated in Fig. $2 a, b$. At the cold conditions the axial and tangential flow velocity components exhibit similar behaviour determining the formation of a pronounced central recirculation zone, with the least flow velocity components near the flow centre $(\mathrm{R}=0)$ and the peak ones close to the channel walls (at $r / R \approx 0.8$ ). At constant primary and secondary swirling air supply rates the recirculation zone extends up to $L / D \approx 1$ (Fig. $2 c$ ). Further downstream, the air swirl motion close to the channel walls gradually weakens with enhanced air swirl motion close to the flow centre. Moreover, the local measurements of the air velocity components have shown that the secondary swirling air supply into the combustor promotes the upstream and downstream swirling airflow expansion, with the upstream swirl flow reversing from the layer of wood pellets, which determines the observed increase of the air swirl velocity near the flow centre (Fig. $2 b, d$ ). A similar swirl flow reversal downstream of the axis was observed by the authors of [14] for the conditions when the number of local swirls exceeds the critical value. For the conditions of an empty gasifier the shape of tangential and axial velocity profiles is influenced by the primary swirling air supply rates that determine formation of the primary recirculation zone close to the primary swirling air nozzle with a reverse axial flow close to the bottom part of the gasifier, and a high level of the axial flow velocity pulsations (Fig. 2e,f).

For the given configuration of our experimental device the wood fuel gasification and burnout of volatiles is initiated by the radial injection of propane flame into the upper part of the wood biomass layer, with direct impact on the formation of the swirling flow velocity profiles downstream of the combustor which depends on the combustion conditions nearby the gasifier outlet. First, the experimental study of formation of the mentioned profiles was carried out for the conditions of self-sustaining wood fuel burnout, when the propane flame injection into combustor is interrupted immediately after ignition of the volatiles (prop $=0$ ) $(t \approx 200-250 \mathrm{~s})$. Next, to assess the effect of propane co-fire on the flow dynamics, 

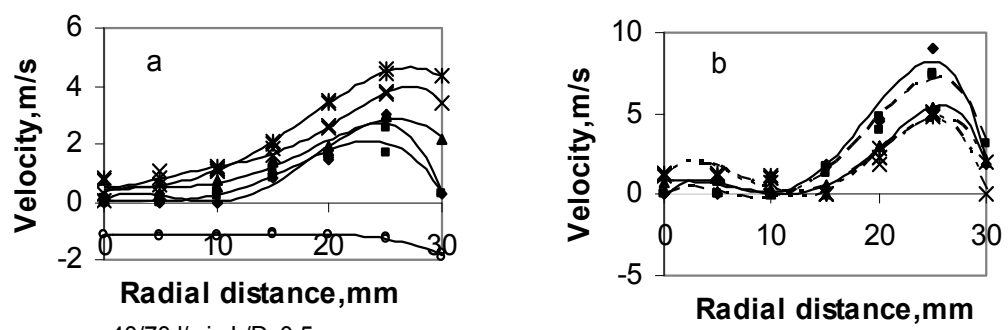

- vax,40/70 l/min,L/D=0,5

- vax, air-47/70l/min

A vax,air-55/701/min

* vax, air-40/100/min

- vax, air 40/70l/min;L/D=-0,3 upstr. flow

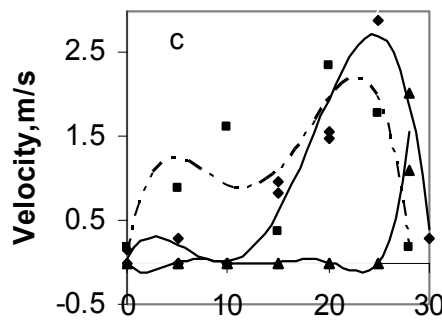

Radial distance, $\mathrm{mm}$

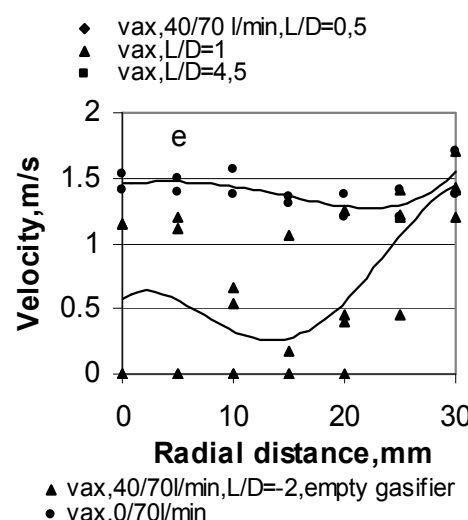

- vtg,cold air-40/100l/min;L/D=0,5

vtg, air $40 / 70 \mathrm{l} / \mathrm{min} ; \mathrm{L} / \mathrm{D}=0,5$

$\times$ vtg,air-47/70//min

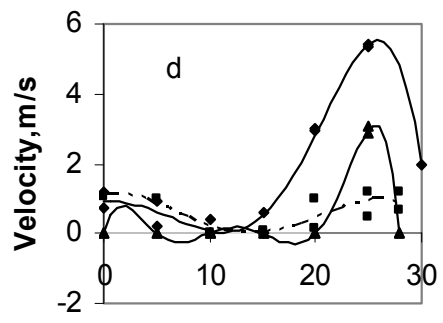

Radial distance, $\mathrm{mm}$

vtg, air 40/70 l/min;L/D=0,5 $\mathrm{vtg}, \mathrm{L} / \mathrm{D}=1$

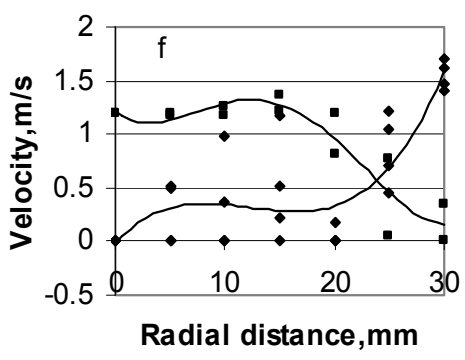

- vtg,40/70I/min,L/D=-2,empty gasifier - vtg, $0 / 70 \mathrm{l} / \mathrm{min}$

Fig. 2. Typical variations in the shape of tangential $\mathrm{v}_{\mathrm{tg}}$ and axial $\mathrm{v}_{\mathrm{ax}}$ velocity profiles at different rates of primary and secondary air supply above the layer of wood pellets $(\mathrm{L} / \mathrm{D}=0.5)(a, b)$ and different distances above $(c, d)$ and below $(\mathrm{L} / \mathrm{D}=-2)(e, f)$ the secondary air nozzle for the conditions of peak mass load of the wood pellets $(c, d)$ and empty gasifier $(e, f)$.

the experimental research on the formation of the flame velocity profiles downstream of the flame channel flow was conducted at a constant rate of the additional heat energy supply of $1.25 \mathrm{~kJ} / \mathrm{s}$ into the flame of volatiles. It should be noted that the propane co-fire with heat added to such flame accelerates the flame temperature rise up to the peak value, increasing the temperature of the flame reaction zone by $150-200{ }^{\circ} \mathrm{C}$ and providing the wood fuel burnout at a nearly constant temperature of the reaction zone and, respectively, a nearly constant rate of the heat energy production in the time interval $t \approx 500-1550 \mathrm{~s}$ (Fig. $3 a, b$ ). At increasing the rate of propane supply into the burner and the propane thermal capacity $\left(Q_{\text {prop }}\right)$ up to $1.25 \mathrm{~kJ} / \mathrm{s}$ the ratio of propane co-fire $\left(Q_{\text {prop }} / Q_{\text {tot }}, \%\right)$ for given combustion conditions gradually increases up to $30-35 \%$ of the total heat output produced 
downstream of combustor $\left(Q_{t o t}\right)$ and can approximately be expressed as a square function of the heat produced by propane co-fire (Fig. $3 c$ ).
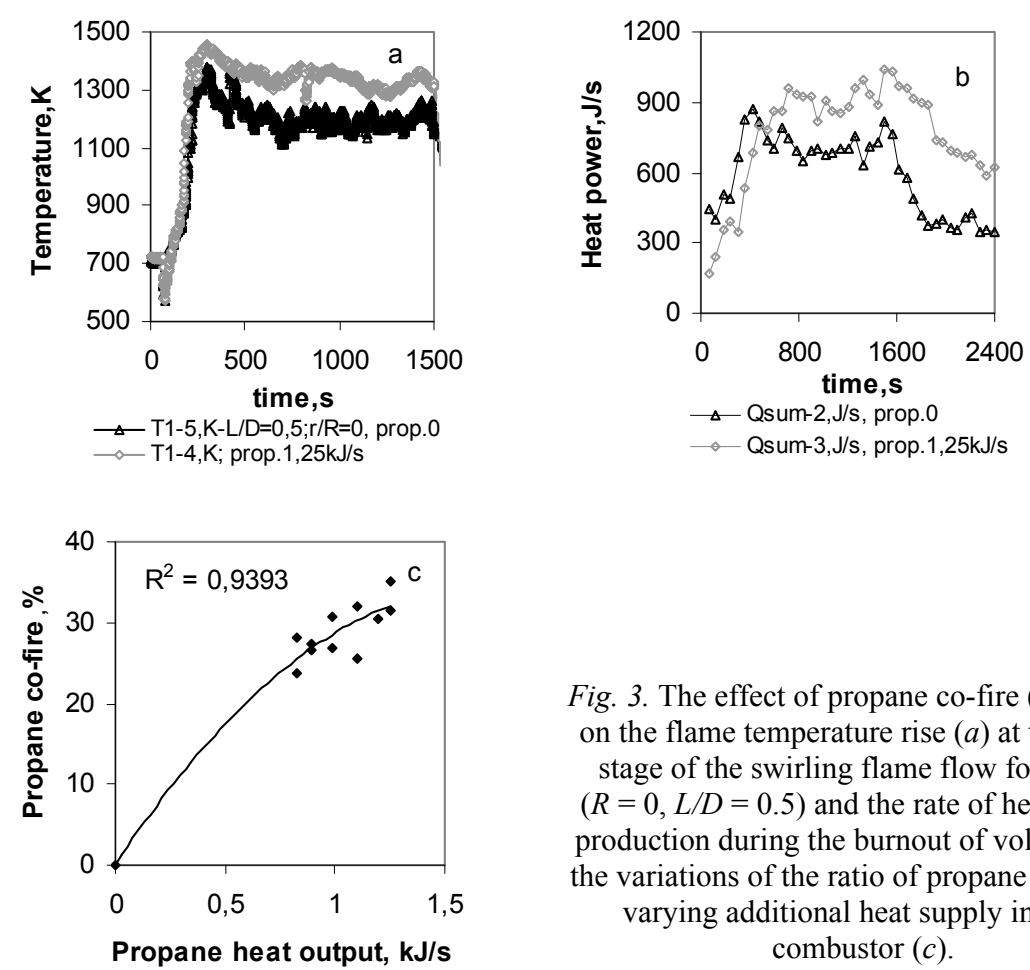

Fig. 3. The effect of propane co-fire $(1.25 \mathrm{~kJ} / \mathrm{s})$ on the flame temperature rise $(a)$ at the initial stage of the swirling flame flow formation $(R=0, L / D=0.5)$ and the rate of heat energy production during the burnout of volatiles $(b)$; the variations of the ratio of propane co-fire by varying additional heat supply into the combustor $(c)$.

Since the structure of the swirling flame flow is closely connected with the formation of swirling airflow field, two factors are of importance: those determining the formation of the tangential and axial velocity profiles of swirling flame downstream of the combustor. First, the formation of such profiles is influenced by the swirling airflow dynamics giving rise to the recirculation zone near the flame axis with swirl-induced reverse axial motion of the hot products up to the wood fuel layer where the flame components are actively mixed. The second decisive factor is that the formation of the mentioned profiles is influenced by the interrelated processes of swirl-induced reverse heat and mass transfer to the surface of the wood layer. As a result, there are observed more intense wood fuel heating, gasification, ignition and burnout of the volatiles developing at different rates of the wood fuel burnout and of the heat production under the conditions of selfsustaining wood fuel combustion and propane co-fire (Fig. 3b). It is estimated that, while at the self-sustaining wood fuel burnout (prop. $=0$ ) its average rate does not exceed $0.135-0.14 \mathrm{~g} / \mathrm{s}$, at the co-fire with additional heat energy supply of $1.25 \mathrm{~kJ} / \mathrm{s}$ it increases up to $0.2 \mathrm{~g} / \mathrm{s}$, which means enhancement of the burnout process. Both for the conditions of self-sustaining wood fuel burnout and propane co-fire a typical feature of the formation of flame velocity profiles is increased thermal load of the flow field in comparison with non-reacting cold swirling 
airflow. Such an increased thermal load promotes the radial and axial expansions of the flame flow field that shift the peak values of the axial and tangential flame velocity components closer to the channel walls up to $r / R=1$ (Fig. 4a,d). In fact, the differences of the wood fuel burnout rates under the conditions of selfsustaining burnout and those of propane co-fire mean variations in the thermal load of swirling flame, and, consequently, variations in the axial flow rates which disturb the balance between the axial flow rates and recirculating flame components. The self-sustaining wood fuel burnout indicates a faster establishment of the balance between the axial flow rate and the recirculation with the least axial
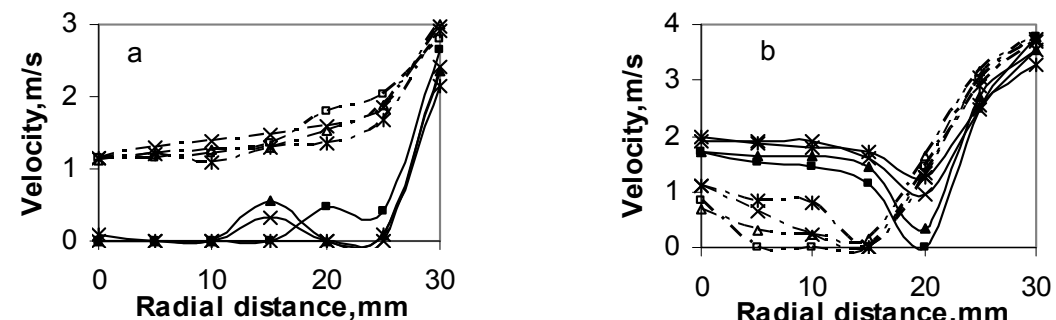

—_ vax-2,prop.0;L/D=1

$\longrightarrow$ vax-3,prop.0

$\stackrel{*}{*}$ vax-4,prop.0

- - vax-5,prop. 0 . $25 \mathrm{~kJ} / \mathrm{s} ; \mathrm{L} / \mathrm{D}=1$

- - - - - vax-3,prop. $1,25 \mathrm{~kJ} / \mathrm{s}$

- - * - - vax-5,prop. $1,25 \mathrm{~kJ} / \mathrm{s}$
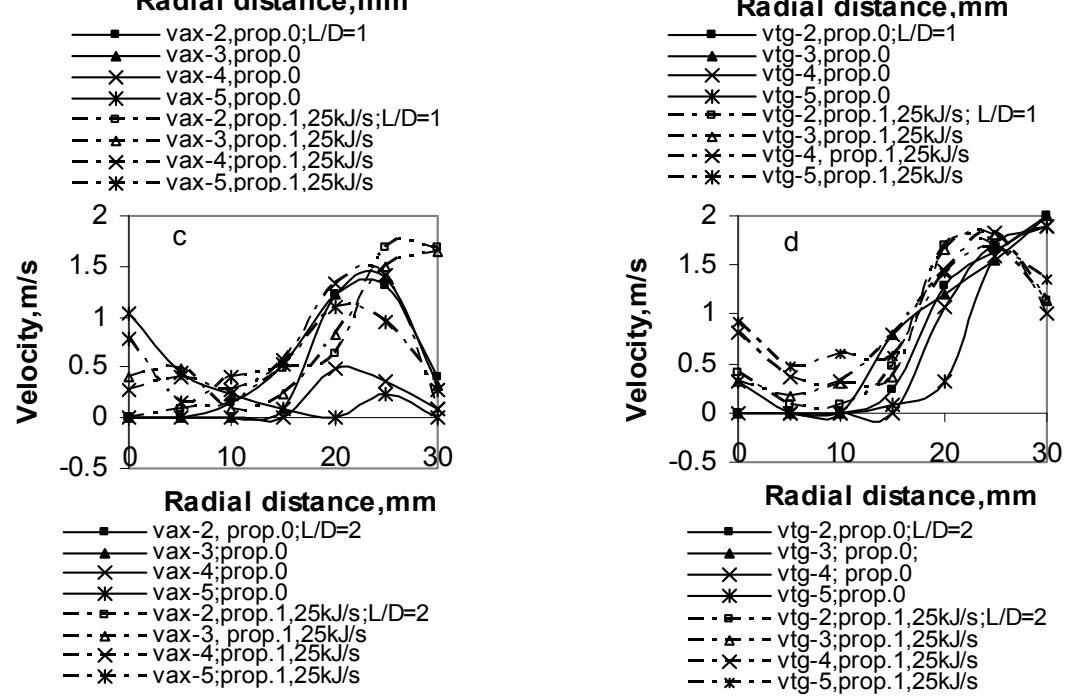

$\longrightarrow$ vtg-2,prop.0;L/D=2

vtg-3; prop.0;

$\longrightarrow$ vtg-4; prop.

苇 vtg-5;prop.0

- - - vtg-2;prop. $1,25 \mathrm{~kJ} / \mathrm{s} ; \mathrm{L} / \mathrm{D}=2$

- - - - vtg-3;prop.1,25kJ/s

$-* *$ - vtg-4,prop.1,25kJ/s
$--*$ - vtg-5,prop.1,25kJ/s
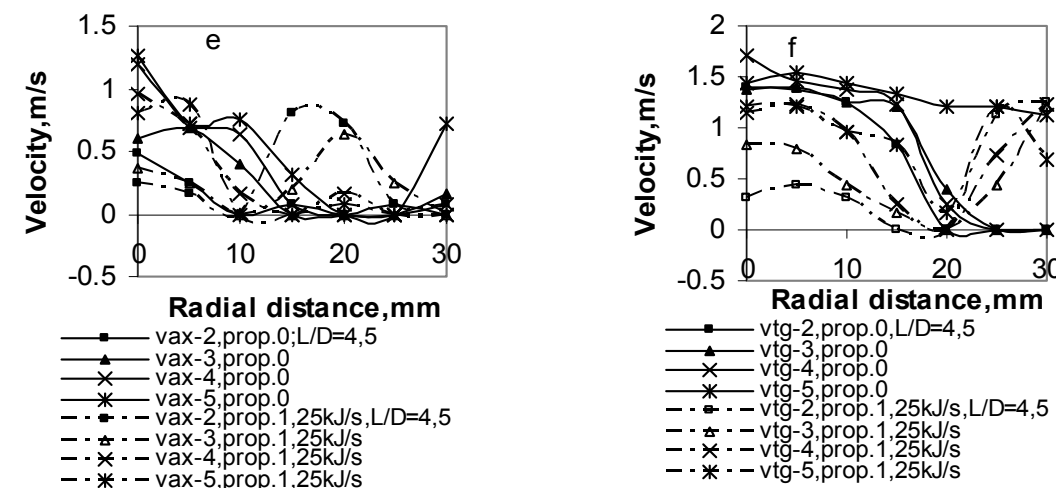

Fig. 4. Formation of the swirling flame velocity profiles downstream of combustor at different stages of the wood fuel burnout $(2-t=500-700 \mathrm{~s} ; 3-t=700-900 \mathrm{~s} ; 4-t=900-1100 \mathrm{~s}$; $5-t=1100-1300 \mathrm{~s})$ and constant rate of propane co-fire $(1.25 \mathrm{~kJ} / \mathrm{s})$. 
flame velocity as early as at $L / D \approx 1$ and more active swirl flow reversing from the wood layer near the flame centreline $(r / R<0,5)$, where the dominant mixing of the flame components and combustion of the volatiles is initiated. Higher axial flow velocity with reduced swirling flow reversal near the flame centre was detected for the conditions of propane co-fire (Fig. 4a,b), when the enhanced wood fuel gasification and combustion of volatiles restricts the swirl-induced recirculation and shifts the balance between the axial flow of volatiles and the recirculation further downstream - up to $L / D \approx 2$. Time-dependent variations in the formation of swirling flame flow structure immediately after ignition of volatiles $(t=500-700 \mathrm{~s})$ when the recirculation of hot products dominates, indicate the formation of the minimum value of the axial flow velocity close to the flame centreline $(r / R<0,3)$. During the next stage of volatiles burnout $(t>700 \mathrm{~s})$ the axial flame velocity close to the flame centreline is gradually increasing with radial expansion of the flame velocity profiles thus disturbing the local balance between the axial flow of volatiles and the recirculation (Fig. $4 c, d$ ).

As could be seen, similar variations in the flame velocity profiles occur downstream of the combustor (up to $L / D \approx 4.5$ ): the peak values of the axial and tangential flame velocity components along the outer boundary layer of recirculation zone gradually decrease and the flow pattern approaches the flame centreline with radial expansion of the flame reaction zone during the wood fuel burnout (Fig. $4 a-f$ ). When comparing the swirl flame velocity profiles at this stage of the flame formation for the conditions of self-sustaining wood fuel burnout (prop. $=0$ ) and the propane co-fire it is seen that the most substantial difference in the formation of these profiles is along the outer boundary layer. As follows from Fig. 4, in the conditions of propane co-fire the tangential flame velocity profiles indicate the formation of a more complex structure with two peaks of swirl velocity, separated by its least value close to the outer boundary of recirculation zone (at $r / R \approx 0.7$ ). As is seen in Fig. $4 e, f$, the least flame swirl velocity refers to the peak value of the axial flame velocity that during the wood fuel burnout gradually decreases and shifts to the flame centreline at the end stage of the wood fuel burnout $(t>1200 \mathrm{~s}$ ), when the enhanced burnout restricts recirculation (Fig. 4e,f).

\subsection{The main factors of formation of swirling flow composition field at co-firing the wood fuel with propane.}

As shown above, the formation of flame velocity profiles for the given configuration of the experimental set-up is highly influenced by the swirling flame dynamics promoting the recirculation of hot products and determining the formation of the reverse axial heat/mass transfer up to the wood layer with enhanced wood fuel heating, gasification and burnout of volatiles developing at different rates during the processes of the self-sustaining wood fuel burnout (prop. $=0$ ) and the propane co-fire. The measurements of the flame composition profiles at different rates of propane co-fire confirm that the swirl-induced formation of a central recirculation zone at $r / R<0.3$ with enhanced reverse axial heat/mass transfer of the hot products up to the wood layer results in an enhanced wood fuel gasification and combustion of volatiles, determining the formation of 
the peak volume fraction of $\mathrm{CO}_{2}$ and the peak mass fraction of $\mathrm{CO}$ close to the flame axis (at $r / R<0.3$, see Fig. $5 a, b$ ). The enhanced wood fuel gasification and burnout of the volatiles at propane co-fire results in a correlating increase in the heat energy output and in the flame temperature (Fig. $3 a, b$ ) up to the top of the flame recirculation zone $(L / D \approx 4.5)$. This promotes the radial expansion of the flame velocity, composition and temperature profiles with correlating increase in the combustion efficiency, while decreases the air excess downstream of the combustor (Fig. 4e, 5e, 6a,b, 7a-f). As seen in Fig. 7, the dominant increase in the combustion efficiency is close to the outer boundary layer of the recirculation zone $(r / R>0.5)$, where the swirl-induced recirculation promotes enhanced mixing of the flame components and burnout of the volatiles.
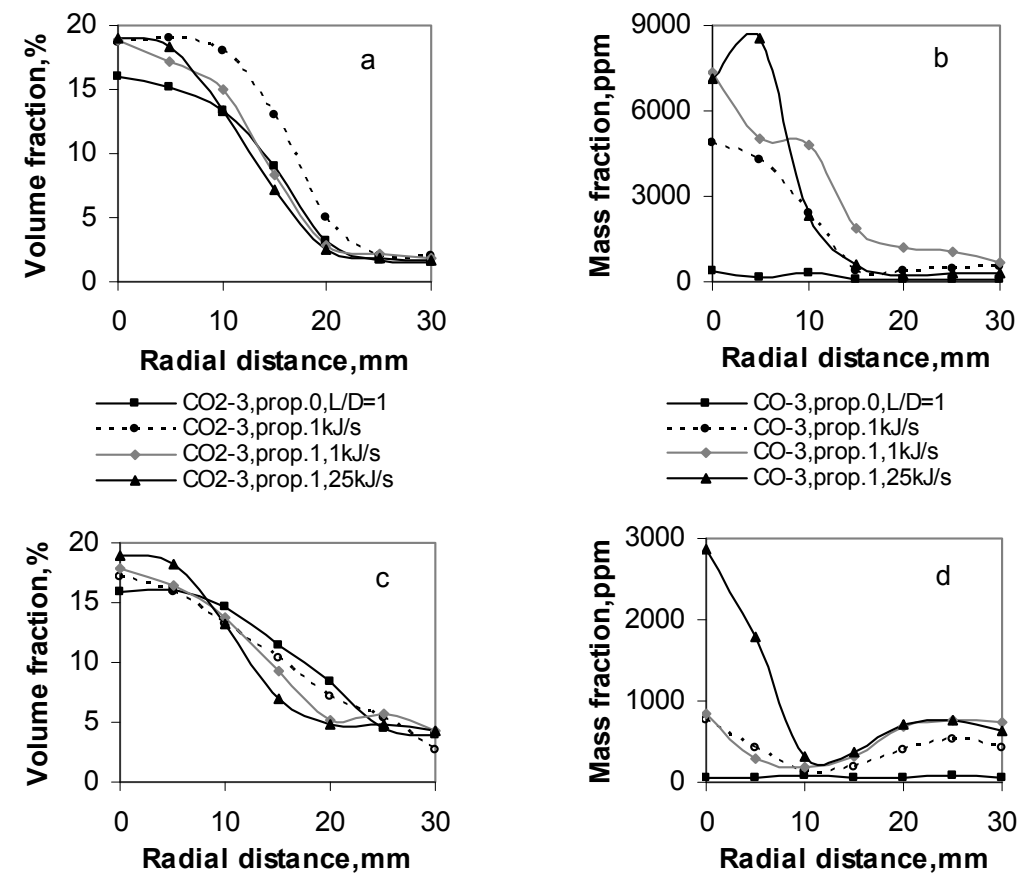

$\longrightarrow$ CO2-3,prop.0,L/D=2

- - - . . . CO2-3,prop.1 $\mathrm{kJ} / \mathrm{s}$

$\longrightarrow$ CO2-3,prop. $1,1 \mathrm{~kJ} / \mathrm{s}$

$\longrightarrow \mathrm{CO} 2-3$, prop.1,25kJ/s

$\longrightarrow$ CO-3,prop.0,L/D=2 - - - . CO- CO- prop. $1 \mathrm{~kJ} / \mathrm{s}$ $\longrightarrow$ CO-3,prop. $1,1 \mathrm{~kJ} / \mathrm{s}$
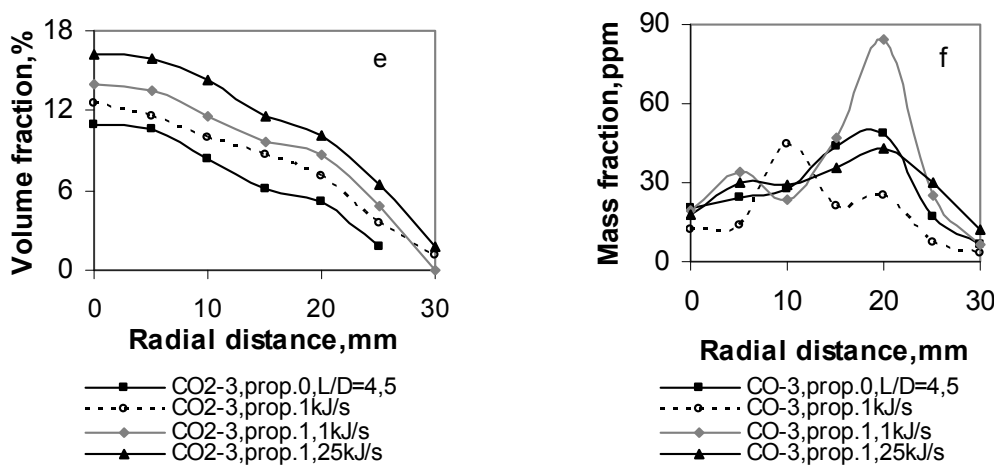

Fig. 5. Effect of propane co-fire on the formation of $\mathrm{CO}_{2}$ and $\mathrm{CO}$ profiles downstream of the combustor during the wood fuel burnout ( 3 for $t=700-900 \mathrm{~s}$ ). 
As is clearly seen in Fig. $5 b, d, f$, the peak value of the $\mathrm{CO}$ mass fraction rapidly decreases downstream of the flame axis $(R=0)$, which confirms that the swirl-induced recirculation results in an enhanced mixing of the flame components completing the burnout of volatiles downstream of the flame recirculation zone $(L / D=4.5)$ (Fig. 5f). At this stage of the swirling flame formation a slight increase in the $\mathrm{CO}$ mass fraction with high level of turbulent fluctuations in the flame at increasing rate of propane co-fire is observed close to the outer boundary of the recirculation zone $(r / R \approx 0.6-0.7)$, where the peak value of $\mathrm{CO}$ mass fraction correlates with those of the axial flow velocity and combustion efficiency, while the flame swirl velocity approaches the minimum value (Fig. 4e,f, Fig. 7e). The formation of the peak $\mathrm{CO}$ mass fraction close to the outer boundary layer (at $L / D=4.5$ and $r / R=0.6-0.7$ ) dominates during the primary stage of the enhanced wood fuel gasification and burnout of volatiles $(t<1200 \mathrm{~s})$ and rapidly decreases during the wood fuel burnout when the wood layer thickness gradually decreases, while the swirl flow reversing from the wood layer results in increasing peak values of the axial and tangential flame velocity components close to the flame centreline (Fig. 4e,f). The measurements of the flame temperature and composition $\left(\mathrm{CO}_{2}, \mathrm{NO}_{\mathrm{x}}\right)$ profiles at different stages of the flame formation indicated the correlations between the local variations in the volume fraction of $\mathrm{CO}_{2}$, mass fraction of $\mathrm{NO}_{\mathrm{x}}$, and flame temperatures in the flame reaction zone. The highest flame temperature with, correspondingly, the highest combustion efficiency and $\mathrm{CO}_{2} \& \mathrm{NO}_{\mathrm{x}}$ concentrations at the least air excess (Fig. 7b,d,f) and the mean $\mathrm{O}_{2}$ concentration are found near the flame axis $(R=0)$, i.e. within the central recirculation zone. Moreover, the radial expansion of the flame temperature profiles (Fig. $6 a$ ) at more intense propane co-fire correlates with the radial expansion of the flame composition and combustion efficiency profiles (Fig. 5e, Fig. $6 b$, Fig. $7 e$ ), thus indicating the influence of propane co-fire on the flame characteristics.
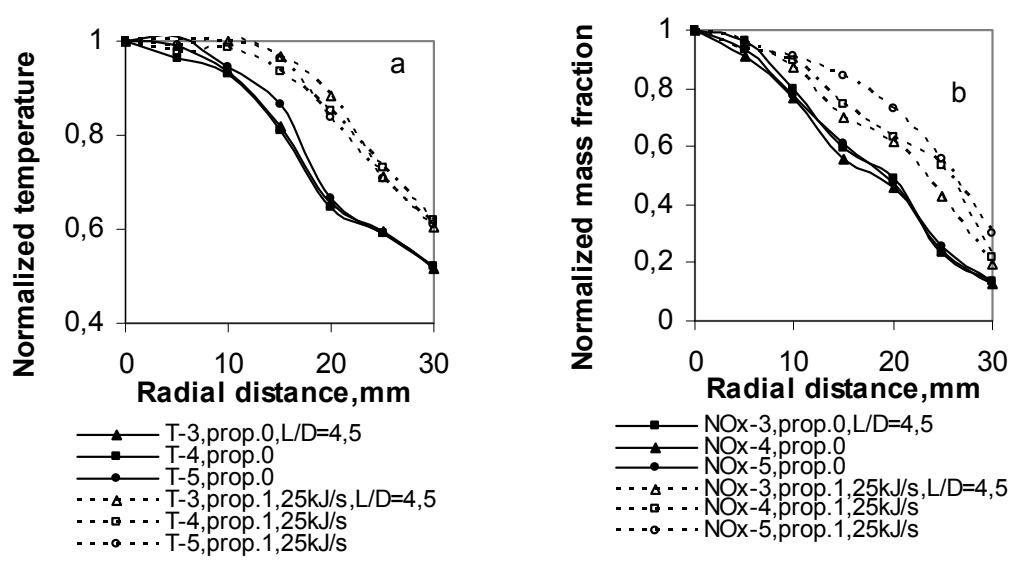

Fig. 6. Effect of propane co-fire on the formation of flame temperature and $\mathrm{NO}_{\mathrm{x}}$ mass fraction profiles in the flame reaction zone at different stages of wood fuel burnout $(3-t=700-900 \mathrm{~s} ; 4-t=900-1100 \mathrm{~s} ; 5-t=1100-1300 \mathrm{~s})$. 

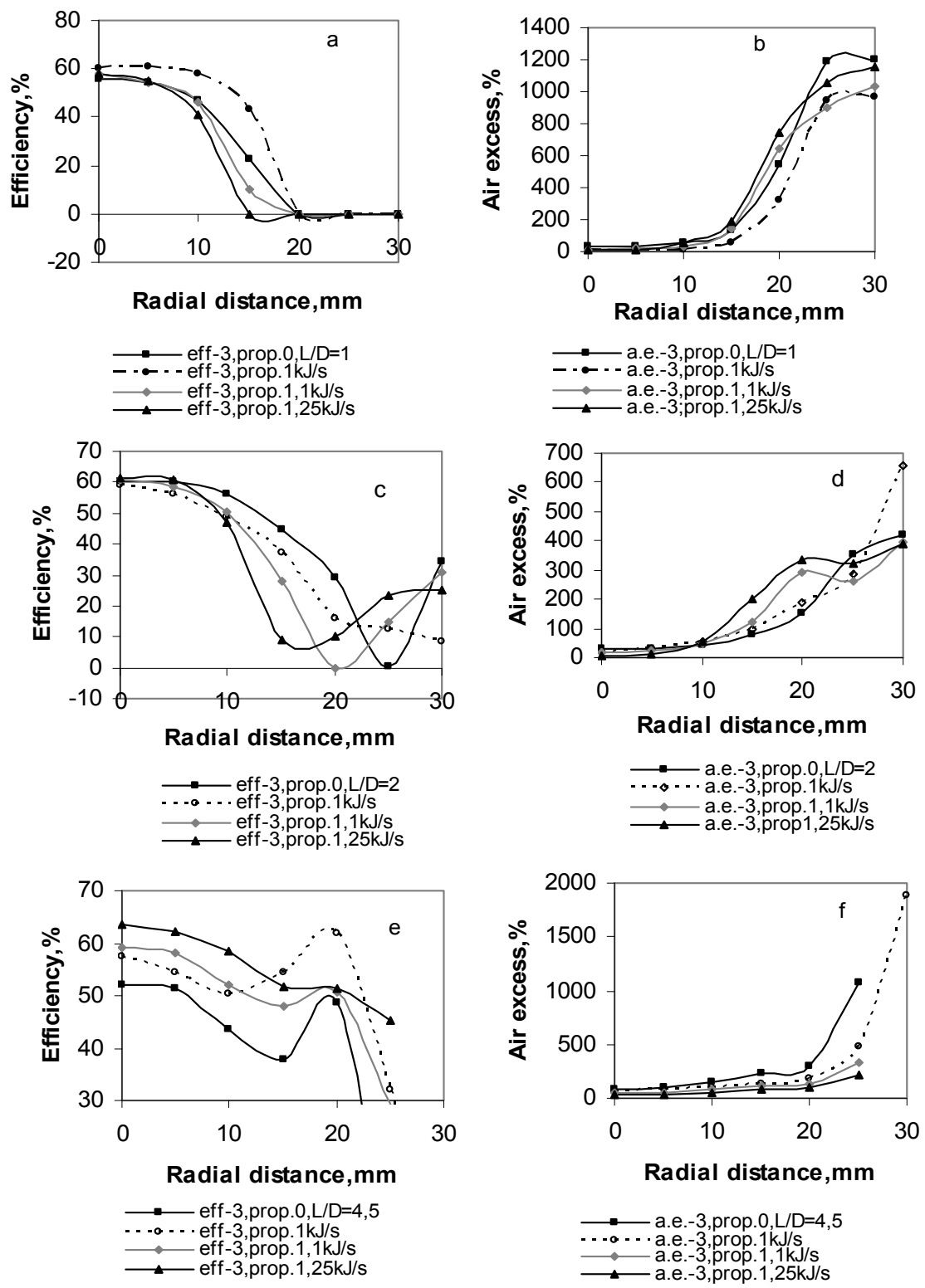

Fig. 7. Effect of propane co-fire on the formation of combustion efficiency and air excess profiles at different stages of the burnout of volatiles.

Moreover, the radial expansion of the flame temperature profiles with correlating expansion of the $\mathrm{NO}_{\mathrm{x}}$ mass fraction profiles along the outside part of the swirling flame flow (Fig. $6 a, b$ ) indicates that the formation of $\mathrm{NO}_{\mathrm{x}}$ under the given combustion conditions mostly refers to the temperature-sensitive two-stage mechanism. In the near-stoichiometric or lean systems this mechanism looks as follows:

$$
\begin{aligned}
& \mathrm{O}_{2} \leftrightarrow \mathrm{O}+\mathrm{O} \\
& \mathrm{O}+\mathrm{N}_{2} \leftrightarrow \mathrm{NO}+\mathrm{N} \\
& \mathrm{N}+\mathrm{O}_{2} \leftrightarrow \mathrm{NO}+\mathrm{O}
\end{aligned}
$$


The most active NO formation by this mechanism occurs in the flame zone with the highest temperature and the air excess of $30-100 \%$.

The measurements of the flame composition have shown that at the rates of propane co-fire up to $25-30 \%$ the peak value of the $\mathrm{NO}_{\mathrm{x}}$ mass fraction in the products is relatively low and does not exceed $100 \mathrm{ppm}$, which is quite acceptable for the wood fuel burnout. The average value of the $\mathrm{NO}_{\mathrm{x}}$ mass fraction in the flame reaction zone approaches $66 \mathrm{ppm}$ at the average value of the $\mathrm{CO}$ mass fraction during the burnout of volatiles $28-30 \mathrm{ppm}$ and combustion efficiency $60 \%$, indicating that the propane effect of co-fire on the flame swirling flame formation can be used to achieve clean and effective wood fuel burnout.

\section{CONCLUSIONS}

The developed laboratory-scale combustor for the wood fuel \& propane cofire allowed the complex experimental research into the propane co-fire effect on the formation of the flame velocity, temperature and composition profiles.

Measurements of the flow patterns demonstrate that the formation of the flame velocity profiles is dictated by the air swirl, i.e. by induced formation of the central recirculation zone with intensive mixing of the flame components and combustion of the volatiles.

For the given combustion conditions the propane co-fire promotes the radial expansion of the flame velocity profiles with correlating increase in the combustion efficiency, flame temperature and local concentration of the main products $\left(\mathrm{CO}_{2}\right.$ and $\mathrm{NO}_{\mathrm{x}}$ ) along the outside part of the flame reaction zone and resulting increase in the total heat output downstream of combustor $\left(Q_{t o t}\right)$.

It is found that for the given rates of propane co-fire the dominant $\mathrm{CO}_{2}$ release (up to $80 \%$ ) refers to the carbon-neutral emissions produced during the burnout of renewable wood fuel at the least average $\mathrm{CO}$ mass fraction in the products (28-30 ppm). Moreover, for the given combustion conditions the average $\mathrm{NO}_{\mathrm{x}}$ fraction in the products does not exceed 60-70 ppm. Hence, the propane cofire of the wood fuel downstream of the swirl flame flow can be used to provide cleaner and more effective burnout of wood fuel.

\section{REFERENCES}

1. Global warming (2009). Union of Concerned Scientists, http://www.ucsusa.org/.

2. Stephens, E.A., Williams, L.D., \& Nicholas, N.S. (2003). The Role of Renewable Energy in Reducing Greenhouse Gas Build-up, 1-4. http://www.tva.gov/environment/air/ontheair/renewable.htm.

3. Climate Change Home (2009). U.S. Environmental Protection Agency, http://www.epa.gov/climatechange/index.html.

4. Biomass Co-Firing in Electric Utility Boilers. Primenergy (Oklahoma, Tulsa), http://www.primenergy.com/reference_BioMassFiring.htm.

5. Chunyang, $\mathrm{Wu}(2006)$. Fuel- $\mathrm{NO}_{\mathrm{x}}$ Formation during Low-Grade Fuel Combustion in a Swirling-Flow Burner. PhD Theses, Brigham Young University, 1-230.

6. Drennan, S. (1982). First co-firing gas burner optimized on computer reduces particulate emissions 24\%, saves \$0.13/MMBtu. Journal Articles by Fluent Soft Users, $1-4$.

7. Babu, S.P. (2001). Role of Natural Gas in Promoting Bioenergy as a Component of the Sustainable Energy Scenario. Natural Gas/Renewable Energy Hybrids Workshop, 
NETL, Morgantown, WV, 1-12, http://www.netl.doe.gov/publications/proceedings/ 01/hybrids/ ngbm8-01.pdf.

8. Vanoverberghe, K.P., \& Vandenbulck, A.V. (2003). Confined annular swirling jet combustion. Combust. Sci. and Tech., 175, 545-578.

9. Vanoverberghe, K.P. (2004). Flow, Turbulence and Combustion of Premixed Swirling Jet Flames. Doctoral theses. K.U. Leuven, dept. Mechanical Engineering, div. TME: Leuven, Belgium, 1-225.

10. Littlejohn, D., Majeski, A.J., Tonse, S., Castaldini, C., \& Cheng, R.K. (2002). Laboratory investigation of an ultralow $\mathrm{NO}_{\mathrm{x}}$ premixed combustion concept for industrial boilers. Proceedings of the Combustion Institute, 29, 1115-1121.

11. Barmina, I., Desnickis, A., \& Zake, M. (2008). The effect of combustion dynamics on the formation of pollutant emissions by co-firing the wood biomass with gaseous fuel. Heat Transfer Research, 39 (5), 379-389.

12. Barmina, I., Desnickis, A., Gedrovics, M., \& Zake, M. (2006). Experimental study of combustion dynamics by co-firing the renewable with fossil fuel. Sci. Proceedings of Riga Technical University, ser. Power and Electrical Engineering, Vol. 17, 174-188.

13. Zake, M., Barmina, I., Gedrovičs, M., \& Desnickis, A. (2007). Effective technology of wood and gaseous fuel co-firing for clean energy production. Latv. J. Phys. Tec. Sci. 2, 41-56.

14. Physics of Swirling flow. (2009).

http://www.personal.psu.edu/yxw145/physics\%20of\%20swirling\%20flow.htm.

15. Molero de Blas, L.J. (1998). Pollutant formation and interaction in the combustion of heavy liquid fuels. PhD thesis, University of London.

\title{
KOMBINĒTĀ ATJAUNOJAMĀ UN FOSILĀ KURINĀMĀ DEGŠANAS PROCESA DINAMIKAS EKSPERIMENTĀLIE PĒTĪJUMI VIRPUL,PLŪSMĀ
}

\author{
M. Zaķe, I. Barmina, V. Kriško, M. Gedrovičs, A. Descņickis
}

Kopsavilkums

Veikti kombinētā atjaunojamā (koksnes biomasa) un fosilā kurināmā (propāna) degšanas procesa dinamikas eksperimentālie pētījumi virpuḷplūsmās ar mērķi izveidot ekologiski tīrus un efektīvus koksnes biomasas degšanas un siltuma ražošanas procesus, mainot papildus siltuma padevi gaistošo savienojumu degšanas zonā. Eksperimentālo pētījumu komplekss apvieno ātruma sadalījuma, liesmas temperatūras, sastāva un degšanas procesa efektivitātes radiālā un aksiālā sadalījuma veidošanās pētījumus dažādās kombinētā degšanas procesa attīstības stadijās, mainot propāna padevi liesmā. Pētījumu rezultātā parādīts, ka propāna padeve koksnes biomasā ierosina âtrāku koksnes gazifikāciju, nodrošinot pilnīgāku gaistošo savienojumu sadedzināšanu virpuḷplūsmas recirkulācijas zonā, kurā notiek intensīva gaistošo savienojumu sajaukšanās ar liesmas komponentēm, palielinot degšanas zonas temperatūru, kas atkarīga no papildus siltuma padeves gazifikātora izejā.

09.11.2009. 